\title{
Euclides da Cunha na Alemanha
}

\author{
BERTHOLD ZILLY
}

\begin{abstract}
A DE OUTUBRO DE 1897, o diário Vossische Zeitung noticiava na primeira página de sua edição matutina: "O governo brasileiro anuncia oficial1 mente que as suas tropas tomaram a cidade de Canudos no estado da Bahia e prenderam o líder dos fanáticos, o Conselheiro. Confirmando-se tal notícia - e desta vez ela surge de forma muito clara -, então pode-se parabenizar a República pelo sucesso, pois ainda há poucos dias as tropas governamentais foram rechaçadas diante de Canudos. $\mathrm{O}$ assim chamado bando de fanáticos ameaçava seriamente a República, entretinha estreitas relações com o partido monarquista.
\end{abstract}

O deflagrador do movimento foi o profeta Ántonio Conselheiro, sendo seu nome verdadeiro Antonio Maciel. O nome de Conselheiro ele só recebeu de seus sequazes. Ele tem 63 anos e prega como profeta já desde o ano de 1875 . (...) Depois de muitos anos de vida solitária e arredia, ele apareceu como pregador no interior do estado da Bahia. Entre os habitantes pobres e ignorantes dessas regiões ele passava por santo, e logo tinha reunido tantos crentes ao seu redor que pôde fundar uma vila própria. Nessa colônia ele imperou como príncipe absoluto, dispondo sobre a vida e a morte. Recusou-se a pagar qualquer taxa ou imposto ao governo e expulsou os fiscais. Depois de alguns anos, o Conselheiro desistiu da primeira colônia e fundou mais para o interior a cidade de Canudos. Hoje esta cidade conta mais de 10 mil habitantes e possui várias igrejas com muralhas extraordinariamente resistentes. Todos os crentes andam sempre armados e também as mulheres são treinadas nas armas. Enquanto vigorou o Império, o Conselheiro pregou apenas a salvação das almas, mas depois da introdução da República ele a declarou obra do demốnio e anunciou a volta de um príncipe que faria a Monárquia resplandecer em um novo brilho. (...) Mesmo com toda a paciência, o governo brasileiro viu-se por fim forçado a marchar com o poder das armas sobre o cabeça dos fanáticos, já que com a precária situação econômica ele ganhava diariamente multidões de adeptos. (...) Se o movimento termina com a prisão e provável execução do Conselheiro, isto ainda vai se revelar. Talvez o messias brasileiro tenha providenciado um sucessor."

O artigo do grande diário liberal berlinense contém, ao lado de imprecisões insignificantes, os fatos decisivos e as mentiras propagandistas do conflito. 
A 5 de outubro de 1897 a guerra contra Canudos, no profundo sertão baiano, cerca de $\mathbf{4 0 0}$ quilômetros ao norte de Salvador e $\mathbf{2}$ mil quilômetros ao norte do Rio de Janeiro, depois de 11 meses e inúmeras declarações precipitadas de vitória, chegava efetivamente ao fim, de forma muito mais sangrenta do que podia imaginar o redator alemão, abastecido de notícias peläs agências internacionais. É verdade que não houve execuções em sentido jurídico - o Brasil abolira havia muito tempo a pena de morte -, mas aqueles entre os vencidos que não tinham morrido na luta, ou de fome, sede ou doença, estes foram assassinados sumariamente pelos soldados vencedores, com o consentimento de seus superiores, indo até o ministro da guerra. Pouparam-se apenas poucas centenas de mulheres e crianças, as quais foram em parte vendidas, pelos membros do exército, como escravos a comerciantes e bordéis ou oferecidas como soupenirs a amigos. $O$ próprio Euclides ganhou um menino-jagunço, que ele todavia apoiou nos estudos e mais tarde - certamente de maneira refletida -impulsionou para o magistério.

Canudos, que nos quatro últimos anos se alçara com seus 20-30 mil habitantes à condição de segunda maior cidade da Bahia, já não existia mais no dia 8 de outubro. As ruínas das suas duas igrejas e $\mathbf{5 . 2 0 0}$ habitações foram dinamitadas, incendiadas, demolidas pedra por pedra, viga por viga, parede por parede, $e$ arrasadas a fim de extinguir todo e qualquer resquício da comunidade insubmissa: Por esse motivo não podia haver um sucessor imediato para o Conselheiro, mas perduravam a miséria social e o contexto espiritual aos quais ele havia dado expressão; assim ele não foi a única figura messiânica dos pequenos agricultores, arrendatários, vaqueiros e miseráveis do sertão inóspito, castigados pelo clima, pelos latifundiários e pelas autoridades.

No mais, os fatos reais não se estampam no artigo citado de maneira mais tendenciosa do que em muitos órgãos de imprensa brasileiros. Pois a guerra na remota Canudos foi - de maneira tão bárbara quanto moderna - uma guerra de destruição e extermínio. Desde o início os habitantes não tinham chance alguma, pois o simples fato de pertencerem à comunidade os condenava à morte, à medida que não haviam fugido a tempo. Governo e exército nem sequer acharam necessário adverti-los, ameaçá-los, estabelecer exigências e condições, negociar com eles; fizeram com que as armas falassem com exclusividade. Foi uma agressão sem declaração de guerra. E os agressores lutaram não só com as armas mais modèrnas da indústria armamentista européia como também com recursos psicológicos, a fim de mobilizar a opinião pública, apoiados pelos jornais que de certo modo torpedeavam, de todas as posições, os moradores da miserável cidade de taipa, tendo a imprensa mundial por aliado. Também o correspondente de guerra Euclides da Cunha participou inicialmente dessa campanha. Em nome da República e do progresso, até mesmo em nome da Revolução de 1789, os adeptos do Conselheiro foram estigmatizados como loucos, criminosos, inimigos do Estado, sendo-lhes questionado propagandisticamente o direito de existência. 
Como na maioria das guerras modernas, havia também em Canudos uma rigorosa censura da imprensa e um desvirtuamento calculado da opinião pública. Não podia vazar nada a respeito dos crimes de guerra; ao invés disso, o exército espalhava afirmações abstrusas sobre ligações dos defensores com o partido monarquista e sobre o abastecimento de armas a partir do exterior.

Por 11 meses essa guerra civil localizada abalara o imenso país com crescente intensidade $e$ por sete meses inquietara até mesmo a opinião pública mundial, mobilizara no total $12 \mathrm{mil} \mathrm{sol-}$ dados, quase a metade do contingente brasileiro de então - junto com canhões Krupp e outros armamentos pesados - e custara ao exército cerca de $\mathbf{1 . 1 0 0 ~ m o r t o s ~ e ~ q u a t r o ~ m i l ~ f e r i d o s . ~ A m e a c ̧ a r a ~ a ~}$ consolidação da jovem República sob o seu primeiro presidente civil, desde 1894 no cargo, assim como a sua recuperação econômica e, com isso, também seu crédito internacional. $O$ alívio pela vitória era compreensível. Começaram então, de fato, anos de relativa estabilidade política e prosperidade econômica.

Todavia, mal fora disparado o último tiro e em parte da opinião pública operou-se uma reviravolta na avaliação da guerra. Apareceram então artigos de jornal, panfletos e livros sobre atrocidades do exército, redigidos sobretudo por estudantes e formados das faculdades de direito $e$ medicina da Bahia. Até mesmo o sentido da guerra toda foi, não raro, colocado em dúvida. Mas mesmo quem não ia tão longe, expressava freqüentemente seu pesar pela morte de tantos sertanejos, detratados antes como jagunços, como bandidose que agora, como estavam mortos, eram declarados concidadãos e incorporados à nação. Iniciativas para um enaltecimento dos inimigos encontraram-se até mesmo nas últimas ordens do dia do exército. Também uma série de oficiais que lutaram em Canudos e escreveram mais tarde sobre a campanha reconheceram posteriormente $o$
Os sertóes na Alemanha"

Marcus V. MazzaRT"

OPResentr taxto do Berthold Zilly saiu originalmente como posficio a sua tradugăo para o alemio d'Os sertipes de Buclides da Cunatia, publicada em outubro de 1994, pela edirora Suhrkamp, sob o título Krigg im Sertĩo (Gmarra no sertio).

Entre as obras da literatura brasileira traduzidas para 0 alemão, talvez tenha sido esta a que obteve maior ressontncia, o que ex pode verificar pelas resentias, sempre elogioses, que salram etn vários dos mais importantes jornais e revistas do pals: um extenso comentário nobre Os sertīes abre o "panorama da literatura brasileira" de Hugo Loetscher publicado numa edição especial da revista Spiegrl (outubro 94) dedicada a Feira Internacional do Livro de Frankfurt, que teve - Brasil como pafs homenageado. Em períbdicos como Die Zeit, Frankfurter Rundschaw, Suiddewtscbe Zeitung, Frettug, Euclides foi saudado, em longas e entusiásticas resenhas, como um Herodoto do sertî, um Épico de dimensö́cs bombricas. Pela sua traduçao, B. Zilly recebeu em agosto de 1995 o reckm-criado Prémio Scatched (10 mil marcos) e em novembro, na cidade de Ravensburg, o conceituado - Premio Wieland (15 mil marcos), outorgado a cada dois anos pelo estado de Baden- 
heroísmo e a brasilidade dos habitantes primitivos do sertão. Assim o exército pôde orgulhar-se duplamente, de si próprio e do adversário.

Poucos anos depois a nação começa a esquecer os aspectos questionáveis e revoltantes da guerra. Urgiam outras tarefas. Vivia-se uma euforia de modernização. $O$ Rio de Janeiro e outras grandes cidades civilizavam-se. A necessidade de informações quanto à Guerra no fim do mundo - como diz o título de um romance de Mario Vargas Llosa que remonta a Os sertões - estava aplacada. Por meio de reportagens, análises e relatos militares, livros de memórias escritos por testemunhas com perspectivas variadas, os aspectos essenciais da guerra estavam focalizados e, de certo modo, esclarecidos, até mesmo com apoio visual de um álbum de fotografia comercializado; e também a necessidade de comoção e entretenimento estava, num primeiro momento, satisfeita por alguns poemas, peças de teatro e romances. Podia-se deixar que o acontecimento deplorável, mas curiosamente também edificante, se assentasse aos poucos.

Aparecem então, no final de 1902, Os sertões de Euclides da Cunha.

O autor teme o fracasso ou mesmo represálias, pois por um lado o livro sobre a guerra no sertão perdera atualidade nesse meio tempo, cinco anos após os fatos retratados; por outro lado, o livro critica instituições poderosas, entre elas a imprensa e sobretudo o exército, não poupa sequer o comandante geral da última campanha.

Mas $O s$ sertões tornam-se uma sensação, um daqueles livros não muito freqüientes na história literária cujo significado é reconhecido desde o início e cujo impacto permanece inalterado por décadas afora. Em oito dias são vendidos 500 exemplares, a metade da edição; a segunda edição segue-se após alguns meses - espantoso para um país de 18 milhões de habitantes, dos quais a maioria se compõe de analfabetos, e só alguns poucos milhares formam aquela camada de acadêmicos em condições de ler a obra carregada de tanta erudição. No Brasil foram publicadas até hoje mais de quarenta edições do livro e, além disso, ele está traduzido para mais de uma dúzia de línguas. Há ainda adaptações de episódios em forma de revista em quadrinhos, livros infantis ou folbetos, a tradicional literatura de cordel. Pintores e desenhistas são inspirados pelos Sertões. Intérpretes da brasilidade declaram ser o livro a bíblia da nação, críticos literários, a epopéia nacional. Trechos da obra, considerada dificil do ponto de vista lingüístico, entram em livros didáticos e antologias, e também as disciplinas das ciências sociais e humanas, que vêm surgindo desde os anos 30, fazem dela leitura obrigatória. Uma torrente bibliográfica - jornalística e acadêmica - vem sendo publicada até os dias de hoje. Em suma: Os sertões são, desde o início, um dos livros mais famosos do Brasil, embora não dos mais lidos, mais admirado do que amado, às vezes também temido pelos alunos - um clássico, um monumento. 
O autor é coberto de honrarias; mesmo os militares, excetuando-se alguns poucos, esboçam um sorriso amarelo ou até saúdam o livro. Ủm ano após a publicação, o engenheiro e jornalista de ocasião Euclides da Cunha, 37 anos completos e até então desconhecido, já está eleito membro das duas mais significativas associações de autores do país, a Academia Brasileira de Letras espécie de Académie Franf̧aise do Brasil - e o Instituto Histórico e Geográfico Brasileiro. Essa dupla homenagem é índice da dupla recepção do livro: o mais exigente crítico literário do Brasil, José Veríssimo, saudou-o logo após a publicação como "o livro de um homem de ciência, um geógrafo, um geólogo, um etnógrafo; de um homem de pensamento, um filósofo, um sociólogo, um historiador; e de um homem de sentimento, um poeta, um romancista, um artista, que sabe ver e descrever, que vibra e sente tanto aos aspectos da natureza como ao contato do homem, $\mathrm{e}$ estremece todo, tocado até ao fundo da alma, comovido até às lágrimas, em face da dor humana, venha ela das condições fatais do mundo físi$\mathrm{co}$, as secas que assolam os sertões do norte brasileiro, venha da estupidez ou maldade dos homens, como a campanha de Canudos." José Veríssimo, contudo, censura o excesso de termós técnicos e arcaísmos, uma crítica que até hoje se faz ouvir. Considerando mais atentamente a sua análise, veremos que ele subdivide as ciências entre aquelas que operam antes com mensurações e aquelas que se baseiam antes no compreender, de tal forma que Os sertões reúnem em si três espécies de produção intelectual, as ciências exatas, as ciências sociais e a beletrística. Estas "três culturas", como Wolf Lepenies as chama, que um Diderot $\mathrm{e}$ um Goethe ainda conseguiam abarcar, também estavam dissociadas no Brasil de então, mas jamais de forma tão ampla como na Europa, pois o ensino superior no país ainda não possuía todas as faculdades e, sobretudo, a divisão intelectual do trabalho estava menos avançada. Acresce-se a isso que
Württemberg (Wieland -o patrono do prêmio, foi também o primeiro tradutor de Shakespeare na Alemanha).

Se o êxito d'Os sertōes se deve em primeiro lugar as suas qualidades ińtrínsecas, então há que se ressaltar de imediato a competência com que essas qualidades foram transpostas para o alemão. Uma tal empresa, levada a cabo ao longo de vários anos, tem certamente suas raízes em profundas afinidades eletivas; mas foi também através de intensas leituras, de exaustivas pesquisas que o tradutor se familiarizou com os menores detalhes, as alltimas sutilezas do epos euclidiano. Não precisou, é certo, criar uma linguagem que sugerisse ao leitor a impressão de uma fala dialetal, como fez o tradutor alemão do Grande sertão: veredas, Curt Meyer-Clason. De qualquer modo, o empenho de Zilly em manter máxima fidelidade ao estilo de Euclides, em transpor para a sua versão o tom, o ritmo, $o$ pathos emocional do original, colocou-o também, sistema- ticamente, diante de imensas dificuldades, para as quais encontrou via de regra soluções felizes.

Zilly aventa a hipótese de muitas passagens enigmáticas d'Os sertões, que assim permanecem na sua tradução, representarem no fundo "uma espécie de solilóquio de um pensador contemplativo". Mas, com relação a várias outras passagens mais obscuras, 
Euclides como pesquisador viajante, condição que de certo modo era a sua em Canudos, tinha por modelo eruditos que conheciam os três campos, como Alexander von Humboldt, Martius, Saint-Hilaire, Teodoro Sampaio, os quais ele cita várias vezes.

Os sertões enfeixam sentimentos, opiniões, preferências intelectuais da virada do século, revestem o remorso pelas vítimas da guerra e a autocrítica da nação da roupagem de uma retórica clássica, na qual entraram traços de culto parnasiano da forma, entusiasmo naturalista pela descrição e crença positivista na ciência. Voltando-se para a própria realidade, Euclides vai ao encontro da necessidade de auto-investigação nacional, menos ligada a tendências de época do que o gosto literário e que desde então se tornou um traço cada vez mais importante da vida intelectual brasileira. $O$ livro é enaltecido sobretudo como passo decisivo na descoberta do interior do país, que até então mal se levara em consideração. É verdade que o Modernismo dos anos 20, gerado em São Paulo, e o romance nordestino de crítica social, que se constitui pouco depois, assumiram uma postura antes de incompreensão frente à linguagem e ao estilo de Euclides da $\mathrm{Cu}$ nha, mas retomaram o seu empenho enfático em superar a fixação pela Europa, largamente difundida, em conhecer os próprios compatriotas do interior e sua mentalidade, prestar-lhes ouvidos e integrá-los à cultura nacional. E se o observador e narrador Euclides da Cunha valoriza o sertanejo, aquele mestiço de três raças que o Euclides teórico da sociedade considera um retardatário atávico, então ele prepara de certo modo o terreno para os cientistas sociais e os artistas dos anos 30. O caráter miscigenado do povo e da cultura, que até então passava por mácula e levara gerações de intelectuais brasileiros ao pessimismo e ao ódio introjetado, foi reavaliado por aqueles como uma qualidade e um fator de enriquecimento étnico.

Euclides colocou questões e ofereceu respostas que giravam sobretudo em torno de um problema: quem somos nós brasileiros, divididos pela oposição entre sul e norte, civilização e barbárie, modernidade e atraso, cidade e campo, litoral e sertão? A doutrina dos dois Brasis partiu, nos anos 50 e 60, de tais observações. Se ela foi criticada com razão pela teoria da dependência, uma vez que negligenciou as causas estruturais do assim chamado subdesenvolvimento, as descrições dos fenômenos eram todavia procedentes e o são em parte até hoje. Euclides perguntava ainda: quem são as nossas tão estranhas subcamadas rurais? Qual o futuro do Brasil em face da concorrência internacional e da dominância das potências européias e da América do Norte? Tudo isso são questões de politica desenvolvimentista que permaneceram atuais, embora hoje em dia os fatores clima e filiação étnica não sejam avaliados como por volta de 1900 , quando teorias raciais de cunho social-darwinista eram, em quase toda parte, levadas cientificamente a sério. Nos últimos anos a modernização da agricultura impeliu os habitantes do sertão para as cidades litorâneas e do sul num grau que era 
quase impensável no tempo de Euclides, o que gerou novos problemas sem que os velhos tivessem desaparecido. Uma parte do sertão veio para a cidade.

Euclides prestou uma contribuição expressiva à constituição da consciência histórica brasileira. A repressão do movimento religioso camponês no árido interior da Bahia não foi o único abalo - nem mesmo o mais grave, mais tumultuoso ou com o maior número de vítimas - sofrido pelo jovem país que conquistou a independência em 1822 e o regime republicano em 1889. Se a guerra de Canudos está muito mais presente na memória coletiva e na vida intelectual brasileira do que outras crises comparáveis - levantes, guerras, guerras civis, também mais presente do que a repressão sangrenta do movimento messiânico de Contestado, no sul do Brasil, nos anos de 1910 a 1916 - então isso se deve com certeza ao livro de Euclides. Canudos jamais foi esquecida. De tal forma que o nome desse campo de ruínas passou há alguns anos para outro lugarejo vizinho. No Brasil, porém, quem diz Canudos, diz quase sempre Euclides da Cunha, e assim não causa espanto que - aliás muito antes da recuperação do nome antigo - uma pequena cidade a cerca de 70 quilómetros ao sul, a velha Cumbe, tenha sido rebatizada como Euclides da Cunha.

Também os militares jamais esqueceram Canudos. A cada par de anos um coronel ou general reformado escreve um livro sobre aquela guerra, na maioria das vezes para corrigir Euclides da Cunha. E por anos a fio o exército tentou impedir que se constituísse naquele local um novo povoado - tentativa inicialmente vã, até que se conseguiu impor por volta de 1970 a construção de uma represa no lugar exato da antiga Canudos: uma perversão dos ideais de prática civilizatória de Euclides da Cunha, o qual, de fato, sempre recomendou tais construções, mas cujo livro visa por inteiro a resguardar do esquecimento rebuscadas ou elípticas, ele empenhou-se em clucidá-las, torná-las mais legiveis para o leitor alemão. Os exemplos desse procedimento básico do tradutor se deixariam arrolar às dezenas; para que se tenha uma idéia mais concreta, apresentemos aqui trets exemplos, tomados a cada uma das partes do livro:

No $5^{\circ}$ capítulo de "A Terra", Buclides refere-se ìs trets categorias geograficas esbocadas por Hegel, na Introducăo de sua Filosofia da Historim, como fatores fundamentais de diferenciaçoes étnicas. Mais adiante, após considera; çōes do proprio autor sobre as antíteses climáticas que se - observam nos sertő́es do norte brasileiro, lé-se: "Eles impóem por isso uma divisăo especial naquele quadro." 0 tradutor substitui o "naquele "quadro", nessas alturas bastante distante da referéncia inicial, por "no panorama de Hegel".

No $3^{\circ}$ capítulo de "O Ho.mem", que se abre com uma das frases mais antologicas da nosea literatura, Euclides faz impressionantíssima descrição da seca que martiriza periodicamente o sertanejo. E ao final, o momento doloroso em que este se dobra: "Não resiste mais. Amatula-se num daqueles bandos, que lá se vão caminho em fora, debruando de ossadas as veredas, e lá se vai ele no éxodo penosissimo para a costa, para as serras distantes, para quaisquer lugares onde o não mate o elemento 
a guerra no sertão. No final dos anos 60 a ditadura militar (1964-1985) temeu que se pudesse formar um movimento guerrilheiro em Canudos. E que, efetivamente, houvesse um grupo que fazia tais conjecturas - este fato só parecerá estranho se não se considerar que também os guerrilheiros tinham naturalmente lido Os sertões.

Mas foi sobretudo o Conselheiro que se tornou o símbolo de um cristianismo autodeterminado e combativo, dos pobres do campo. Pois, no fundo, nenhum dos problemas de 1897 está resolvido. De forma alguma decorrem estes apenas da seca. Os conflitos intensificaram-se nos últimos tempos, já que cada vez mais as famílias vêm sendo expulsas da terra que utilizam desde várias gerações. Pastam agora nessas terras, depois de terem sido cercadas, ao invés das cabras dos pequenos sitiantes, as reses dos fazendeiros. Desde o início dos anos 80 existe no sertão de Canudos um movimento religioso que se originou da comunidade de base de Monte Santo, o qual luta pela reforma agrária e reivindica para si a figura de Antonio Conselheiro. O seu spiritus rectoré o Padre Enoque José de Oliveira, nesse meio tempo suspenso de suas funções pela Igreja.

Para a maioria dos historiadores e cientistas sociais o entrelaçamento Canudos-Euclides foi e é tão grande que estes, mesmo não seguindo muitas de suas interpretações datadas, apoiam-se em seu livro como fonte principal. Eles mal retrocederam para trás de Euclides, e até pouco tempo ninguém ousou publicar novamente uma exposição tão ampla e exigente. $\mathrm{O}$ autor d'Os sertĩes parecia, descontando-se algumas análises específicas, ter esgotado o tema. Isso poderia surpreender à primeira vista. Quando se lêem os relatos contemporâneos sobre a campanha, relativamente numerosos, verifica-se que todos os fatos essenciais narrados por Euclides também se encontram naquelas outras fontes, em parte até mesmo de maneira mais exata e completa. Exagerando um pouco: se não houvesse Os sertões, nós, mesmo assim, saberíamos tudo o que sabemos hoje sobre Canudos. Só que, abstraindo-se dos especialistas, quase ninguém iria interessar-se pelo assunto. Não são os fatos e nem mesmo muitas das reflexões que fazem a singularidade do livro, mas sim a sua apresentação estética. Se nenhum historiador ou cientista social pode passar ao largo dos Sertões, então isto significa um triunfo da literatura.

Quem foi o autor desconhecido, cujo primeiro livro - e em certo sentido o único - é Os sertões? Pois o que ele escreveu depois da sua estréia, nos poucos anos até a sua morte precoce em 1909, foram relatos, artigos, ensaios sobre diversos temas históricos, geográficos e políticos, trabalhos dos quais ele reuniu alguns em dois livros, Contrastes e confrontos (1907), e A Margem da História (1909), que trata sobretudo da Amazônia.

Euclides da Cunha, nascido em 1866 no interior do estado do Rio de Janeiro, veio de família pequeno-burguesa; perdeu cedo a mãe, foi criado por 
parentes, cursou a partir de 1886, gratuitamente, a escola militar do Rio de Janeiro, uma típica trajetória escolar para jovens talentosos e sem recursos financeiros.

Desde os anos 70 do século XIX essa escola era um refúgio da modernidade, onde os estudantes podiam adquirir não apenas sólido conhecimento das matemáticas e ciências naturais, mas também considerável formação geral. $O$ influente docente positivista Benjamin Constant (Botelho de Magalhães) via o soldado como "cidadão armado", com missão civilizatória. Discutia-se nessa escola a respeito de obras e correntes literárias e, igualmente, de mazelas da sociedade e da política brasileiras. Para os jovens da classe média baixa o positivismo caiu como uma luva, uma vez que previa reformas sociais através de especialistas, sem a oligarquia, ainda que não necessariamente contra ela, e, sobretudo, sem as massas populares. Idéias, questionamentos, padrões de pensamento, modelos estéticos - desde a Revolução, passando pelo Romantismo e indo até a filosofia contemporânea - vinham na maior parte da França. Os intelectuais do Rio de Janeiro esperavam impacientemente pela chegada dos navios oriundos da Europa, os quais traziam as revistas e livros cobiçados. Enquanto a cultura era apreciada pelas camadas dominantes principalmente como elemento de ostentação e ornamentação, para todos aqueles que se entendiam como progressistas, e sobretudo na escola militar, ela valia como fonte de inspiração na luta pelas grandes reivindicações da época: pela República, pela abolição da escravatura, pela civilização, pelo progresso. E para tudo isso o Império era um empecilho que, ademais, vedava aos muitos filhos da pequena-burguesia representados no exército a ascensão e um lugar na sociedade correspondente às suas capacidades. Os oficiais no início de carreira sentiam-se como vanguarda patriótica, convocados para reformar o país no sentido do positivismo, primordial da vida." $\mathrm{Na}$ versão alemã esse elemento paradoxal, pois ao mesmo tempo vital e mortífero, é elucidado por um aposto: "o sol".

Em uma das partes de "A Luta" - dedicada à quarta etapa da campanha de Canudos, "Nova Fase da Luta", $2^{\circ}$ capítulo -, descrevendo a sede das tropas legais, em número e potencial militar esmagadoramente superiores, pelo sangue dos jagunços, Euclides escreve que estes, caso apare'cessem, "viriam ao encontro de ainda não satisfeito anelo". O tradutor deixa a sarcástica denúncia do autor mais explícita: é o anelo "dos soldados".

Se, portanto, a tradução extrapola o original em alguns momentos é, paradoxalmente, por excesso de fidelidade - menos ao que Euclides objetivou em seu texto do que a intenções e pensamentos implícitos. Os adendos e soluções explicatipas do tradutor, longe de desvirtuarem o caráter do original, são bastante úteis ao leitor alemão às vezes até mesmo imprescindíveis, quando se trata de brasileirismos ou de outros contextos específicos.

Sem querer agora deslocar do primeiro plano o cuidado, o rigor, a sensibilidade com que Zilly traduziu essa grandiosa obra da nossa literatura, há razões para suspeitar que a sua recepção na Alemanha se deva a uma inquietante atualidade do clássico euclidiano. Essa atualidade 
cujo lema Ordem e Progresso deveria adornar a bandeira republicana depois de 1889. Muitos acreditavam-se confrontados com a tarefa de, finalmente - com um atraso de 100 anos -, realizar a revolução burguesa também no Brasil.

Um incidente daquela época (1888) lança luz sobre o caráter de Euclides. Vários cadetes haviam decidido utilizar a visita do ministro da guerra à escola para uma ação de protesto antimonarquista e, em sua presença, arremessar a espada ao chão. Mas no momento decisivo só um fez isto - Euclides da Cunha. A direção da escola sugeriu-lhe pretextar uma crise nervosa como desculpa, mas Euclides, que fora deixado na mão pelos colegas, insistiu corajosamente no caráter político do seu gesto. Como punição ele teve de abandonar a escola. Seu nome, todavia, estava na boca de todo mundo.

O jornal de oposição A Provincia de S. Paulo, desde 1889 O Estado de S. Paulo, convidou Euclides, que já nos anos de juventude tinha ambições literárias - como aluno ginasial escrevera poemas sobre Saint-Just, Danton e outros revolucionários franceses -, para uma colaboração. Assim começou sua atividade jornalística, que deveria ser determinante para a sua vida e aproximá-lo da literatura. Ele assinou os primeiros artigos com o pseudônimo de Proudhon.

Com a proclamação da República, pôde retornar à escola militar, a qual conclui em 1892 na condição de engenheiro militar e com a patente de primeiro-tenente. Como republicano de primeira hora, poderia fazer carreira sem dificuldades, sobretudo nos anos turbulentos da presidência do marechal Floriano Peixoto (1891-1894), mas rejeitou todas as ofertas que extrapolavam o regulamento. Em virtude de sua retidão, seu senso de justiça e sua suscetibilidade, Euclides estava sempre incomodando. $O$ serviço militar o repugnava. Estava decepcionado com o carreirismo, as transações e a presunção de não poucos companheiros republicanos que ocupavam então postos importantes na política. Em 1896 ele deixà o exército para colocar-se a serviço do governo de São Paulo, como engenheiro civil encarregado da construção de estradas e pontes; mas nem nessa profissão, nem em outra qualquer, deveria conseguir uma colocação a longo prazo. Paralelamente, ele voltou a escrever para a imprensa. Também com relação a essa atividade ele tinha fortes reservas. Pensava de maneira muito rigorosa e o que escrevia não era suficientemente fácil para o jornalismo diário. Considerou ligeiramente a possibilidade de tornar-se deputado, uma outra vez ficou na expectativa de uma colocação como professor secundário. Mas esse espírito inquieto, neto do Iluminismo e filho tanto do Romantismo como do Positivismo, via sua verdadeira vocação na literatura, no ensaísmo literariamente exigente. Confessou a um amigo que sua fantasia era como um pássaro que não conseguia levantar vôo do chãọ, mas só de uma árvore. E esta árvore seria o fato concreto.

Um tal fato surge em março de 1897: a derrota da terceira expedição, em 
Canudos, sob o comando do coronel Moreira César. Depois de Euclides ter escrito dois artigos sobre a guerra no sertão, o jornal $O$ Estado de $S$. Paulo o envia em agosto, como correspondente, à região em guerra. Como antigo oficial, ele acompanha o ministro da guerra, de navio, até Salvador, de trem até Queimadas e depois, a cavalo, até Monte Santo, onde o ministro fica para organizar comboios de abastecimentos, ao passo que Euclides segue em direção de Canudos, onde chega em meados de setembro. Pela primeira vez ele vê o sertão. A incumbência confere a virada decisiva ao seu desenvolvimento intelectual. Durante ainda, ou talvez até mesmo antes de sua atividade de correspondente, que termina com a queda de Canudos a 5 de outubro, ele concebe o plano de um livro sobre esses acontecimentos que o convulsionam.

Após o seu retorno, Euclides empregou-se novamente como engenheiro a serviço do governo de São Paulo, desta vez em São José do Rio Pardo, uma pequena cidade a 250 quilômetros ao norte de São Paulo, onde, de 1898 a 1901, reconstruiu uma ponte e ao mesmo tempo trabalhou n'Os sertões. A cidade foi para ele um ponto de tranqüilidade, talvez o único lugar onde esse ser tímido, difícil, às vezes intempestivo, tenha se sentido próximo da felicidade, cercado pela mulher e pelos filhos - que ele, no entanto, freqüentemente negligenciava $-e$ por amigos que apoiavam o seu projeto de escrever o livro e o abasteciam de bom grado com literatura de apoio e informações de toda espécie. No final de 1901 estavam concluídos ambos os projetos, a ponte $\mathrm{e}$ o livro. Até hoje a cidade é o centro de homenagens ao autor que quase assumem a forma de culto. Não é só o fato de a sua antiga moradia servir hoje como museu ao público e aos pesquisadores erigiu-se sobre a cabana de zinco ao lado da ponte, onde nasceram Os sertões, um pequeno pavilhão com o formato de templo em miniatura, $e$ não residiria apenas na crítica, generalizável, da dialética da civilização. $O$ ato de barbárie reconstituído por Euclides pode ser concebido sob o estigma de expurgo étnico que, como sabemos, assumiu formas extremas na Alemanha nacional-socialista. Além disso, Krieg im Sertão apareceu num momento em que recrudesciam, em pleno continente europeu, as atrocidades da guerra civil iugoslava, alcançando na Bósnia a configuração de bomizio generalizado que Euclides desvenda na campanha de Canudos. Esta recente irrupção de animalidade primitiva, para usar outra expressão de Euclides, não terá deixado de influenciar a recepção d'Os sertões na Alemanha. Nessa mesma linha de argumentação $E$. Krippendorff, em resenha mais recente sobre a nossa "epopéia política de dimensões homéricas" (outubro de 95) vislumbra, num capítulo do livro,"a lógica e a dinâmica da 'reconquista' da Tchetchênia pelo estado russo".

Guerras, crimes coletivos, atos de barbárie constituem objeto de não poucas obras da literatura alemã que, como $O s$ sertões, integram a literatura universal. Para demonstrar tal fato não é preciso recorrer à história do século $\mathrm{xx}$ : basta mencionar alguns escritores que tematizaram, das mais variadas perspectivas, a Guerra dos Trinta Anos (1618-48). Em primeiro lugar vem Grimmelshausen, contemporâneo 
todos os anos por ocasião do aniversário de morte do autor acontecem na cidadezinha cerimônias em sua memória, das quais participam não só eruditos e intelectuais mas também gente simples do povo.

Não havia mais dúvida alguma quanto à vocação literária de Euclides. Mas o reconhecimento social não o poupou de preocupações materiais ou domésticas. Parece que nas instâncias superiores se hesitava em conceder-lhe uma colocação fixa e bem remunerada. Ele era demasiado franco, áspero, talvez também demasiado honrado, pouco diplomático. $\mathrm{O}$ ministro das Relações Exteriores, Barão do Rio Branco, incumbiu-o da demarcação das fronteiras do país na região amazônica, mas não lhe ofereceu um contrato de trabalho fixo. No momento exato em que Euclides conseguiu finalmente uma colocação mais segura - um cargo de professor de filosofia numa conceituada escola pública do Rio de Janeiro - e em larga medida poderia ser aquilo que sempre quis ser - isto é, um homme de lettres - sua vida terminou abruptamente com uma catástrofe. Este fim, provocado por ele próprio, está em insólita analogia com a sua concepção da história da natureza e da humanidade, que via entrelaçada com catástrofes.

As tensões conjugais, acumuladas por longo tempo, descarregaram-se por fim de maneira dramática. Euclides não era uma pessoa amorosa, era antes um ser nascido para o sofrer, para o reconhecimento da dor alheia e para o compadecimento. Por certo a estranheza entre os cônjuges foi agravada pela inconstância profissionalmente condicionada e também pela sua ardente ambição literária. Com o fato de que sua mulher amava outro homem, do qual ela até mesmo tinha um filho, Euclides de certa forma, como homem esclarecido e civilizado, parecia ter-se conformado - contrariamente ao arcaico código de honra então em vigor para esses casos, mesmo nas regiões litorâneas de cunho moderno. Mas um dia, poucas semanas depois da sonhada nomeação para professor secundário, no dia 15 de agosto de 1909, ele tentou matar o rival a bala. Este, cadete e exímio franco-atirador, matou-o prontamente. No processo que se seguiu foi absolvido por legítima defesa, embora a opinião pública lhe fosse hostil. Não poucas histórias literárias encobrem esta página obscura da vida de Euclides, falando da bala assassina que arrebatou o grande escritor em meio à sua produção, como se uma celebridade literária não pudesse ser culpada. Sobretudo o autor d'Os sertões sabia demasiado bem quão próximos podem estar urbanidade e brutalidade. No mais, a indústria cultural apropriou-se anos atrás do acontecimento e o transformou no ponto culminante de um seriado televisivo sentimental. E até hoje os descendentes das famílias envolvidas brigam publicamente -em livros, declarações para a imprensa e até mesmo em ações de calúnia - sobre a culpa de seus respectivos antepassados.

Em março de 1897, poucos dias após a divulgação da derrota da terceira expedição, Euclides escreveu seu primeiro artigo sobre Canudos, com o título 
aparentemente estranho de $A$ nossa Vendéia, que em julho iria ter uma continuação intitulađa da mesma forma. O que espanta, visto da perspectiva atual, é o fato de ambos os artigos já conterem, in nuce, Os sertões. a visão do poder do clima e da paisagem, decidindo a guerra e marcando a sociedade, a comparação da campanha com uma guerra colonial, a concepção do sertanejo como encarnação de estágios antigos no desenvolvimento da humanidade, a contradição entre a crítica especializada à condução da guerra pelo exército, ao qual ele deseja a vitória, por um lado, e a admiração secreta pela tática de guerrilha dos defensores, pelo outro lado. Já aqui é notável a descrição plástica antropomórfica, patético-dramatizante, da natureza martirizada do sertão, com minúcias tão exatas, com imagens tão marcantes como se o autor já tivesse estado lá. Mal se fala dos aconteci'mentos do dia. A aspiração, ainda que realizada nos artigos de maneira bastante lacunar, é desde $o$ início mais abrangente, mais rigorosa, mais ambiciosa. Ela visa a sistematização geográfica e histórica dos acontecimentos, a investigação de causas, a descrição precisa de processos selecionados e, mais além, a presentificação quase evocativa de pequenas cenas e grandes quadros. É espantoso que um jornal diário tenha publicado - e não em suplemento literário - artigos científica e literariamente tão exigentes. Os artigos, assim como as reportagens que seguem pouco depois, são tão instrutivos porque exibem, in statu nascendi, o raciocínio e os procedimentos literários do escritor em formação.

De certo modo, Euclides tinha na cabeça o livro sobre o sertão antes de lá chegar, ele enxergara o sertão antes de o ver. Entre o sertão e a sua vida espiritual existia uma afinidade eletiva. Gilberto Freyre o formulou da seguinte maneira: “A paisagem que transborda d' Os sertõesé aquela que a personalidade angustiada de Euclydes da $\mathrm{Cu}$ nha precisou de exagerar para completar-se e do morticínio, que veste a máscara ingênua $\mathrm{e}$ rasteira do seu herói Simplicius Simplicissimus (1669) para, numa profusão de aventuras, retratar a irracionalidade de seu tempo.

Já Friedrich Schiller apoiase numa ordenação sobranceira e harmonizante dos acontecimentos da guerra, de suas inúmeras reviravoltas, para compor sua trilogia dramática Wallenstein (1793. 99), em que decisores individuais se entrelaçam intimamente com razöes de Estado.

Desviando-se largamente de Schiller, mas proximo de Grimmelshausen, vem depois Döblin com seu alentado romance histórico Wallonstein (1920), escrito sob o impacto da Primeira Guerra Mundial. Empenha-se, como se lê num recente ensaio intitulado "Um quadro colossal para míopes' - o outro da Hist6ria no Wallenstein de Döblin", de autoria de Klaus Scherpe, em desativar "os rituais da conceptualização histórica" e contrapor "o potencial do antropológico, do criatural, do natural, do imaginário" a razão ordenadora.

Tambem Brecht, inspirando-se na história do século XVII - e na obra do proprio Grimmelshausen - buscou demonstrar em sua peça Mã̃ Coragem e seus fillos - uma crónica da Guerra dos Trinta Anas as motivaçóes capitalistas que geram $e$ fomentam as guerras. 
exprimir-se nela; para afirmar-se - junto com ela - num todo dramaticamente brasileiro em que os mandacarús e os chique-chiques entram para fazer companhia ao escritor solitário, parente deles no apego quixotesco à terra e na coragem de resistir e de clamar por ela. Resistir quando todos desistem. Resistir sempre. Clamar no deserto. Clamar pelo deserto." E a este deserto pertencem também o homem e a guerra. Quem leu as descrições da natureza em $A$ Terra, sabe porque não são dispensáveis as imagens trágicas de criação e declínio, de vida e luta e morte; entre outras coisas, elas preparam o traçado do caráter do sertanejo e a narrativa trágica da guerra. $\mathrm{Na}$ união com a criatura esfolada, reconhecível naquela parte do livro, repousa a compreensão solidária de Euclides pelos sofrimentos dos jagunços.

O que ressaltá no vocabulário é o imbricamento de expressão regional, dicção científica e o recurso, baseado na cultura burguesa, a analogias com o Velho Mundo - uma trindade que caracteriza também o livro posterior e que resulta de três diferentes maneiras de conhecimento e representação. Desde o início, empenhado pela verdade, o autor está diante de um problema metódico que atravessa todos os seus escritos sobre a guerra e o sertão: como ele deve tornar compreensível, para si e para os leitores orientados pela Europa, a região do Brasil que, a seu ver, é não apenas a mais inóspita como também a mais desconhecida, assim como o mais monstruoso acontecimento da recente história brasileira, se para isso ainda não há os conceitos adequados? Sendo que, dito de passagem, ele exagera o grau dé desconhecimento do sertão da mesma forma como sua singularidade. Mas também o exagero é um venerável e legítimo artifício literário.

Ele tenta, portanto, explicar o desconhecido através do conhecido, processo para o qual ele mobiliza inúmeras comparações, alusões, metáforas e outras expressões figuradas, todo o arsenal da retórica clássica. $\mathrm{E}$ é corrente às pessoas cultas do Brasil a tradição ocidental, especialmente a Antigüidade, o Cristianismo, a literatura e a história da França. Assim, Euclides explica parcialmente o sertão por um desvio pela Europa; traduz a parte desconhecida do Brasil em conceitos e representações ocidentais, dos quais se originam seus parâmetros de comparação e padrões de interpretação. Ele contempla sobretudo a Revolução Francesa como moldura referencial para a guerra de Canudos, sabendo-se nesse aspecto ligado aos republicanos radicais e ao corpo de oficiais. Também mais tarde Euclides conserva o recurso constante ao Velho Mundo. Provisoriamente ele pensa inclusive em intitular o livro planejado de "A nossa Vendéia", antes de decidir-se pelo título primordialmente brasileiro, não metafórico, de Os sertõesneste ponto um desvio de sua maneira comparativa de tecer considerações. Com isso, também chama a atenção menos para a guerra em si do que para o seu cenário, que quase ascende à condição de protagonista. 
Nem sempre a indicação de semelhanças entre o sertão e o Velho Mundo transforma o desconhecido em elemento familiar. Em sua busca desmedida de correspondências, o autor não raro arroja-se em equiparações que mesmo a pessoa mais bem informada não consegue acompanhar e que pressupõem um leitor ideal onisciente. Assim, a comparação conduz ocasionalmente do desconhecido para o ainda mais desconhecido. Esclarecimento completo contradiz a sua concepção do sertão e não seria poético. Talvez as muitas passagens meio enigmáticas do texto sejam também uma espécie de solilóquio de um pensador contemplativo.

Euclides, porém, também estava intuindo: comparaison n'est pas raison. Para aproximar-se da mancha branca no mapa chamada sertão, da qual o homem constitui uma parte, ele necessita também do conceito, da sistemática, da ciência $\mathrm{e}$, como erudito-enciclopédico que é, mobiliza um poderoso arsenal de categorias e conceitos das ciências sociais e naturais - um plano discursivo que igualmente o vincula ao âmbito cultural do Ocidente, ainda que um tal plano seja acessível apenas a um pequeno público. Em seu ímpeto obcecado por minuciosidade e exatidão, o escritor apaixonado pela palavra com freqüência não tem muita consideração para com o leitor e extrapola ocasionalmente os limites da própria competência. Com este procedimento, nós, do mundo de hoje, na Alemanha como no Brasil, devemos ter - em virtude da dissociação avançada entre as mencionadas três culturas - dificuldades ainda maiores do que as que tiveram os letrados entre os contemporâneos do autor. A seleção vocabular, contudo, não está servindo apenas à elucidação e à comunicação, mas também quer impressionar pela sonoridade, pela plenitude e, talvez, até mesmo pelo estranhamento, pois no final das contas também a linguagem científica está a serviço da expressão poética. Assim, o uso abundante de
Mas lembrar apenas obras ficcionais para contemplar $O s$ sertões a partir de outra perspectiva cultural talvez seja injusto para com um autor que, a despeito das poderosas imagens, metáforas e todos os recursos estilísticos de artista épico consumado, via-se sobretudo como historiador $\mathrm{da}$ campanha de Canudos, empenhado em contrapor-se aos deslumbramentos do futuro. Para isso, em não poucas passagens transpôs, pela força imaginativa de criador, fronteiras colocadas à perspectiva historiográfica. Lembremos a esse respeito, por fim, uma reflexão feita pelo fascinante historiador que foi o já mencionado Schiller. No prefácio (de 1788) à sua Historia do desmembramento dos Paises Baixos unidos do reino de Espanba o clássico de Weimar escreve que uma obra histórica rigorosa não precisa sẻr necessariamente uma "prova de paciência" para o leitor; o historiador pode perfeitamente tomar recursos de empréstimo junto à literatura ( $\mathrm{e}$ às outras artes), sem que por isso sua obra se converta em "romance”. São palavras para se ter em mente toda vez que se queira abordar Os sertóesà luz de questões concernentes à relação entre historiografia e representação ficcional da História.

*Marcus Vinicius Mazzari é doutor em germanística e teoria literária pela Universidade Livre de Berlim. 
sinônimos de forma alguma está correlacionado com o ideal científico da correspondência inequívoca de palavra e coisa, gerando antes uma mescla estranha, e certamente desejada, de hiperclareza e vastidão desorientadora. Efeito semelhante surge quando termos técnicos das matemáticas e das ciências naturais, sobretudo da geologia, são empregados metaforicamente e quando se misturam as esferas do animado e do inanimado, do homem e da natureza.

Um terceiro acesso ao sertão oferecem o saber, a linguagem e as habilidades do próprio sertanejo, coisas cujo significado Euclides logo conhece e reconhece. Com muito gosto ele emprega designações regionais para plantas, animais, objetos, atividades da agricultura e dos oficios, não se intimida nem mesmo diante de grosseiros termos dialetais. Como o autóctone é o que mais bem conhece o seu próprio mundo, o autor cientista passa a freqüentar sua escola; recomendando o mesmo ao exército. Muita coisa disso ele traduz na língua do citadino culto, mas muitos termos do sertão permanecem inexplicados, levantam-se solitários e misteriosos no texto como os cereus na caatinga.

E todas essas terminologias e esferas do saber, ultramodernas e arcaicas, confundem-se, como as raças no sertão, numa mestiçagem íntima, que gera um estilo inconfundível. Cuja base é um português só levemente abrasileirado, bastante tradicional no vocabulário e na sintaxe, barroquizante e quase amaneirado, o que acentua a filiação do livro, do autor e do público ao âmbito cultural europeu.

Se Euclides conhecia o sertão antes de o ver, para enriquecer e autenticar a sua fantasia e o seu estilo ele necessitou de um estudo profundo da literatura especializada, a qual the forneceu a matéria-prima dos fatos e não poucas imagens. Esse estudo abarcara já antes de sua partida de São Paulo livros das mais variadas ciências, crônicas, relatos de viagem, ficção. Visto assim, Os sert̃̃es são também um livro sobre livros. Além disso, Euclides, esse visionário exato do sertão, tornou-se - durante o caminho para lá e depois de sua chegada - um incansável observador e pesquisador de campo. Quando chegou, no mês de agosto, em Salvador e foi constrangido a uma estadia de várias semanas, ele aproveitou o tempo para pesquisas em arquivos e entrevistas com soldados e prisioneiros, de tal forma que, sob muitos aspectos, logo estava sabendo mais coisas sobre os bastidores da guerra, sobre a situação na zona de luta e até mesmo sobre a vida no interior do arraial de Canudos, do que seus colegas e, por isso, pôde enviar ao seu jornal, bem antes de alcançar seu destino, relatos de extrema plasticidade. Apesar de seu ensimesmamento Euclides fazia perguntas de forma excelente, conseguia conduzir seus informantes a um máximo de informações. As lacunas, ele as supria com o seu próprio conhecimento prévio e a sua imaginação.

Durante a viagem subseqüente a Monte Santo, passando por Queimadas, ele dá continuidade a essa coleta e a esse registro incansável de todas as informações acessíveis. Tudo o que vê e ouve, ele anota e desenha na única caderneta de 
campo que se conservou: extratos de crônicas e jornais, descrições de utensílios, fragmentos de frases e expressões dos jagunços, mensurações meteorológicas, boatos, impressões visuais, perfis de montanhas, poesia popular dos sertanejos é o livro de anotações de um naturalista, etnógrafo e cronista. A amplidão de interesses assombra. À medida que se aproxima de Canudos, ele vai complementando o conhecimento adquirido através da leitura anterior; $\mathrm{e}$ isto sem modificar substancialmente as reportagens - abstraindo-se da maior concretude de muitos detalhes. No geral, a visão que Euclides tem do sertão e das suas pessoas está consolidada antes da chegada à região e não necessita de qualquer alteração essencial; pautando-nos apenas pela sua representação nos textos, dificilmente poderíamos distinguir as paisagens, acontecimentos e caracteres contemplados com o olho interior dos efetivamente vistos. De outro modo, aliás, não seria possível que Euclides narrasse onze meses de guerra, descontando-se a história preliminar, sendo que nem bem passou três semanas no verdadeiro palco do conflito.

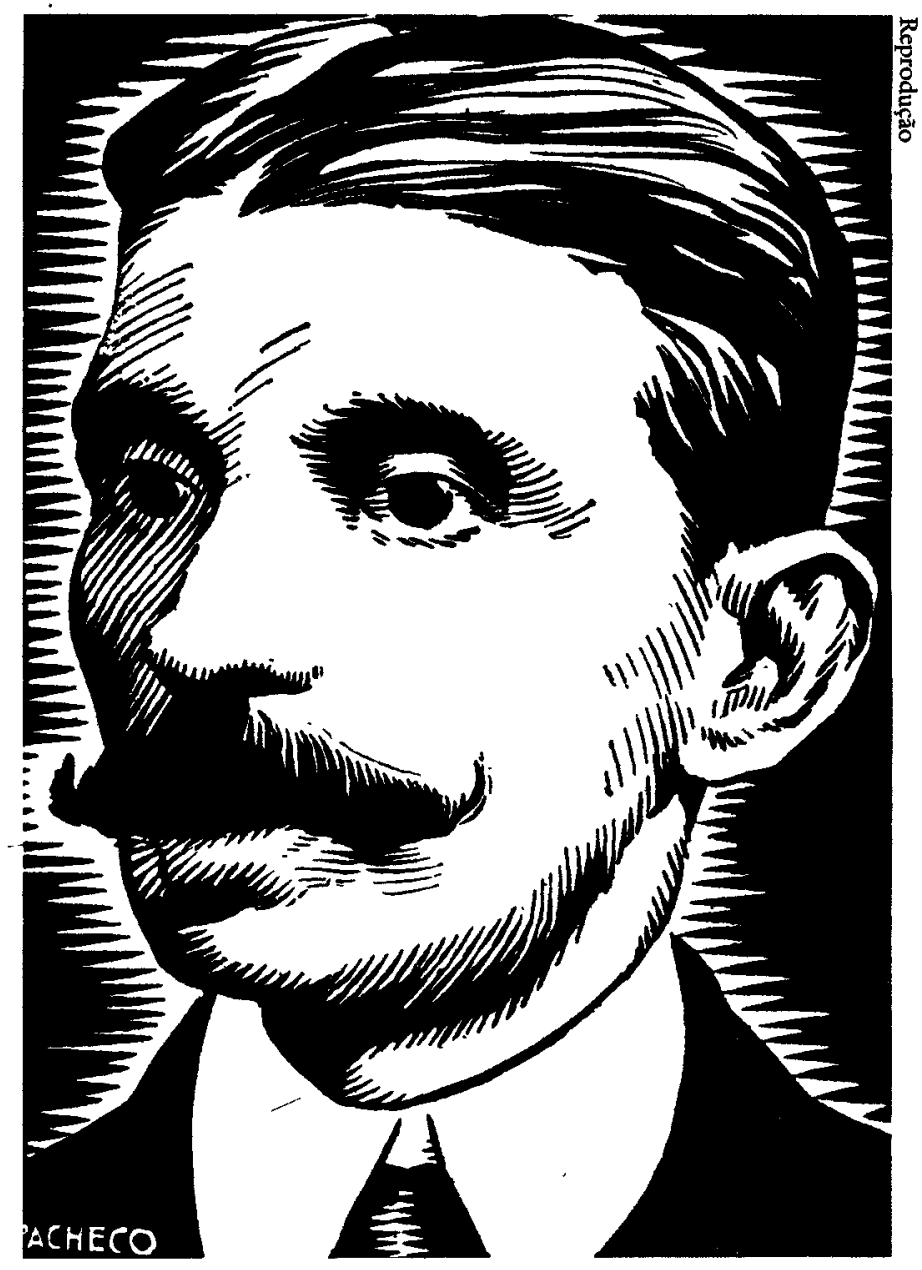

Euclides da Cunha, em desenho de Pacheco

Todavia, o julgamento político dos acontecimentos altera-se. Assim, Euclides vai abandonando aos poucos a tese da conspiração monarquista e começa a julgar a guerra de maneira crescentemente crítica. Sobretudo a sua observação e a compreensão, calcada em empatia, pelos sertanejos prevalecem cada vez mais sobre as teorias antropológicas, bastante datadas da perspectiva atual. Contudo, como sabemos de escritos posteriores, ele jamais abandonou completamente essas teorias, apesar de certas simpatias por concepções socialistas. Poder-se-ia falar de uma vitória da observação e ao mesmo tempo do sentimento sobre prevenções teóricas. 
Há outros aspectos em que a observação e a empatia do autor também lhe corrigem, parcialmente embora, os preconceitos. Imbuído de teorias psiquiátricas da época e de frágeis conhecimentos teológicos, ele considera o Conselheiro não só atávico, mas desequilibrado e herético, um gnóstico, taumaturgo, líder messiânico. Ora, as fontes históricas não corroboram essa tese. As prédicas de Antônio Conselheiro por exemplo, publicadas nos anos 70, não contêm indícios de que ele tenha sido psicopata, nem que se tenha considerado profeta ou messias. Não se arrogou forças milagrosas, não contestou o direito exclusivo dos padres de administrarem os sacramentos, não se afastou da ortodoxia católica da época. É verdade porém que boa parte dos seus adeptos lhe atribuíam essas faculdades.

É preconceito também a afirmação de que se tenha praticado o amor livre em Canudos, interpretação errônea do fato de que temporariamente havia muitos casais vivendo juntos sem a benção da Igreja, devido à grande falta de padres na região. A moral vigente em Canudos era, de modo geral, mais puritana do que libertina.

É igualmente discutível a caracterização do movimento de Canudos como insurreição. $\mathrm{O}$ próprio autor demonstra que a fundação do arraial foi antes uma retirada, uma fuga dianté das forças de repressão, uma iniciativa de auto-ajuda espiritual e social, empreendida por uma população bastante pacífica, abandonada pelas autoridades eclesiásticas e seculares. O governo é que impôs a guerra aos jagunços, aos quais o próprio autor concede o direito de legítima defesa. É verdade porém que a comunidade de Canudos, uma espécie de projeto social alternativo e relativamente bem-sucedido, quase um mini-Estado dentro do Estado, estava começando, pela simples existência e como pólo de atração para a mãode-obra rural em todo o Nordeste, a minar o poder dos mandões regionais, da hierarquia eclesiástica, das autoridades políticas estaduais. Repete-se 'a crônica contradição de Euclides: como ideólogo aceita os estereótipos das elites que supera como escritor.

A tomada de partido por toda criatura leva-o não só a protestar contra os crimes de guerra, mas também a considerar crime a guerra toda, o que ele porém só no livro diz com toda clareza. $\mathrm{E}$ isto, sem que ele tenha questionado a necessidade de uma ofensiva inexorável, até mesmo imperialista, da civilização, também por meios bélicos - como sabemos de publicações posteriores. $\mathrm{O}$ que $\mathrm{o}$ amedronta são os retrocessos bárbaros, atávicos, da própria Civilização, uma vez que tais máculas entre as raças superiores absolutamente não cabem no esquema evolucionista. Ele afirma a civilização e lamenta suas vítimas; uma mediação entre as posições antagônicas não está à vista. Assim, ele não consegue ver seja a História, seja a natureza, senão tragicamente. 
Mas o autor não está cindido apenas entre teoria e simpatia ou entre os partidos beligerantes; freqüentes vezes ele recolhe-se num primeiro momento para trás de exposições alheias. Ele não é um historiador ingênuo que afirma poder narrar os acontecimentos e circunstâncias como tais. As histórias são parte da História. Ele cita, parafraseia, resume, estiliza textos escritos e orais, para cuja seleção ele não conhece tipo algum de reserva. Boatos, artigos, declarações oficiais, pichações de parede, diários, lendas, poesia popular - ele utiliza tudo, com freqüência sem comentar, vez ou outra ironicamente, de tal forma que esses textos avultam num coro polifônico, que intensifica a multiplicidade de vozes presentes no autor mesmo, e este deixa ao leitor a tarefa de formar uma imagem própria da realidade e filtrar a verdade. Euclides esforça-se minuciosamente em reproduzir o mundo imaginário tanto do leitor de jornal do Sul como dos sertanejos do Norte. E assim ele aproxima-se toda vez da realidade através de representações da realidade. Em uma das reportagens, escreve com o rigor do cronista crítico: "Eu sistematizo a dúvida." Mas, com freqüência, sucumbe ao encanto poético das histórias. Quando Euclides reproduz sem comentários lendas e narrativas supersticiosas dos sertanejos ou também dos soldados, percebem-se elementos do real maravilloso da recente literatura latino-americana.

Não raro afirma-se até mesmo o caráter poético de paisagens, pessoas ou acontecimentos. O sertão e a sua guerra sugerem encômios, tragédias, sagas, ou expõem quadros e cenários que clamam por descrição poética. $O$ escritor está incansavelmente empenhado em fixar essas imagens e acontecimentos poéticos.

Desde o início, críticos e leitores debateram-se com a linguagem de dificil compreensão do livro. E embora um tradutor de Euclides tenha experiências dolorosas com essa problemática, ele pode e tem de dizer que os traços estilísticos que subjazem ao juízo são em sua maioria, descontando-se algumas cintilações sonoras, indispensáveis e pertencem à essência do livro. Se Os sertões fossem despidos de todas as dificuldades, de toda pompa estilística, de todas as metáforas arrojadas, todas as palavras raras, todas as figuras retóricas e todas as repetições, eles seriam possivelmente um relato de guerra ou um estudo geográfico-social como muitos outros. Pela tradução, contudo, mal se podem imaginar as dificuldades que o original apresenta ao leitor brasileiro. São em especial as muitas palavras arcaicas e termos científicos, empregados suficientes vezes de maneira metafórica, que fazem mesmo o leitor culto do original estacar repetidamente. Somam-se a isso as muitas referências sintáticas não reconhecíveis de imediato, como por exemplo pronomes aparentemente perdidos no texto. Fica evidente uma tendência ao hermetismo, à qual claramente se contrapõem as freqüentes redundâncias. Frente a isso, a tradução alemã - reproduzindo na medida do possível a singularidade estilística do original - tenta tornar o texto consideravelmente mais legível. Por aqui ele hão possui o nimbo de obra clássica, que no Brasil leva muitos leitores a submeter-se ao esforço da leitura - ou precisamente a evitá-lo. 
O efeito tencionado cairia no vazio se fôssemos tornar mais esguia a sintaxe com sua disposição não raro incomum, sua seqüência de períodos longos, repletos de pausas, que se amontoam de maneira desorientadora, e frases lacônicas, em staccato. E ainda que o epíteto ornamental possa corresponder a uma estética envelhecida - aqui ele é imprescindível. Pois o livro tem o gesto do discurso público, que soa tão alto e tão brônzeo porque deve ressoar vastamente, longamente, sobreviver aos tempos e transpor fronteiras; e isto o autor confia em primeiro lugar aos procedimentos estéticos clássicos. O que já tem tão longa existência, existirá ainda por longo tempo e atuará sobre outros povos. Sabe-se que Euclides, ainda antes do término d'Os sertões, empenhou-se em providenciar uma tradução para o francês. De fato, este relato sobre um ato bárbaro da civilização dirige-se a toda a humanidade civilizada. Um dos mais brasileiros de todos os livros - não tanto pela ambição literária, mas em razão de seu estilo e de sua mensagem - está concebido desde o início como um livro da literatura universal.

O elemento desmedido, desregrado, no estilo e na composição, é expressão desse esforço quase sobre-humano da rememoração, mas com certeza expressão também do prazer pela sonoridade, pelo ritmo e pelà riqueza imagética evocada. Euclides entusiasma-se não apenas por pessoas e coisas, mas também pela língua; a sua é de uma sensorialidade incomum, acústica tanto quanto opticamente, enquanto signo por um lado - imagem sonora e imagem gráfica e, por outro lado, enquanto presentificação do visível e do audível. Como organizador das três primeiras edições ele empreendeu nada menos do que 10 mil emendas, quase todas referentes a ortografia, vocabulário, sintaxe ou tipo gráfico. Em contrapartida, ele mal se preocupou com a correção de errós factuais. Nesse trabalho de aperfeiçoamento do texto, o aspecto estético esteve para ele, sem dúvida alguma, em primeiro plano.

Todavia, essa mobilização de recursos estilísticos não tem nada de $L$ 'art pour l'art; Euclides produz antes uma espécie de hiper-realismo de intensidade fantasmagórica, uma realidade atrás da realidade, penetrante como sonho. Ele quer encantar e fixar o visto. Esforça-se desesperadamente para dizer o indizível, para evocar o sertão não perscrutado, talvez inescrutável, e o caráter misterioso da guerra; ele quer exprimir com palavras a irracionalidade dos homens, de maneira ampla e exata, incisiva e comovente.

Atrás do coro de vozes próprias e alheias eśtá o autor com gesto indicativo, ameaçador e suplicante, como professor, tribuno e pregador. Euclides explica o sertão, acusa os assassinos, clama pelo sertanejo. Embora mal esteja presente no livro enquanto personagem, ele fala a partir de toda linha, sobretudo do estilo, que aqui é efetivamente expressão da personalidade e confere coesão a este livro heterogêneo em tantos aspectos. Muito se escreveu sobre as analogias entre o Conselheiro e Euclidés, sobretudo no que diz respeito aos seus casamentos infe- 
lizes. Ambos, porém, são também mensageiros, que conduzem seus ouvintes através do sertão. Ambos explicam, advertem, rogam. Mas Euclides é um conselheiro inseguro. Falta-lhe a certeza de uma crença ou de uma concepção de mundo solidamente urdida. O leitor é deixado a sós com o seu convulsionamento. Euclides apresenta seus conselhos e perspectivas de ação quase que de passagem: apenas represas e instrução poderiam ajudar o sertão. As divindades profanas da modernidade no entanto parecem ser pouco confiáveis. A civilização assassina, que enviou o soldado, deve enviar agora o engenheiro e o mestre-escola. Ela já poderia ter feito isto antes da guerra, motivo pelo qual esta foi supérflua e um crime. E a ciência deve investigar a psique das massas irracionais de maneira ainda melhor. De quais massas? Daquelas do sertão ou daquelas da região litorânea? Isto fica em aberto. Mas como a civilização pode ajudar os habitantes ignorantes do sertão se ela própria apresenta traços criminosos e loucos?

O discurso de Euclides é uma defesa cujo estilo segue a tradição do genus sublime, sobre o qual Manfred Fuhrmann, explicando e citando Quintiliano, escreve em seu livro $A$ retórica antiga (Die antike Rhetorik): "O estilo patéticosublime está reservado a assuntos de suficiente dignidade; ele só entra em consideração quando se trata de valores altos e supremos, de morte e vida, honra e ultraje dos envolvidos ou bonança e ruína do Estado. Ele acumula brilho, pompa e grandiosidade, ou (...) anseia por sombria paixão. Ele dispõe soberanamente - nos limites colocados à prosa - do vocabulário mais seleto; ele coloca a seu serviço as figuras mais engenhosas e amontoa de maneira ousada, aguda, períodos ritmados. Utilizando corretamente todos esses meios, o estilo sublime (...) irá 'chamar os mortos de volta à vida ... e até mesmo fazer com que a própria pátria levante a sua voz'."

Bem, já que a comunidade de Canudos está aniquilada, o discurso consagra-se à memória dos mortos. Os sertões são um discurso fúnebre em duplo sentido, pois por um lado os adeptos do Conselheiro já morreram, por outro lado Euclides teme que a raça miscigenada, tendente à homogeneidade, dos sertanejos - que poderia ser a base e a rocha viva da nação ainda em formação - seja esmagada antes do tempo pela civilização, em um processo secular do qual a guerra contra Canudos foi apenas um elo intermediário. Esse discurso contém assim a advertência premente de que a nação não deixe as coisas irem tão longe e não volte as armas contra si própria. $O$ discurso de defesa pelos sertanejos ainda viventes soa de maneira estranhamente sombria, como se o próprio autor não acreditasse na salvação e fosse aquele também um discurso fúnebre antecipado.

A rememoração inclui os soldados tombados, assim como vale também para as plantas ressequidas e os animais que morreram de sede, vale para todo o sertão torturado, pois natureza e humanidade estão repletas de criação e ocaso, luta e vitória e derrota, de breves alegrias e longos sofrimentos. Ainda que a 
inclusão de outras vítimas possa à primeira vista diminuir a memória dos sertanejos, estes estão sem dúvida alguma em posição central, são as vítimas principais, são enaltecidos e declarados heróis em face da morte. E os mais corajosos dentre os soldados são igualmente sertanejos, os quais saem a campo contra os seus conterrâneos. Outro traço trágico.

Se o Conselheiro se dirige à sua comunidade do sertão e a Deus enquanto instância suprema, o público de Euclides é infinitamente mais numeroso, mais indeterminado $\mathrm{e}$ anônimo. Ele dirige sua palavra à opinião pública da nação nas cidades litorâneas; além disso, às pessoas cultas do mundo e a uma instância de certo modo metafisica e ainda assim real, a posteridade dos leitores.

Berthold Zilly é doutor em Romanística e professor do Instituto Latino-Americano (Lateinamerika-Institut) da Universidade Livre de Berlim. Traduziu Os sertões para o alemão.

Tradução de Marcus V. Mazzari. O original em alemão encontra-as à disposição do leitor no IEA-USP para eventual consulta. 